\title{
Penggunaan Vub Padi Untuk Pemanfaatan Lahan Bekas Tambang Pasir Kuarsa di Belitung Timur
}

\author{
Use of Paddy Vub for the Utilization of Quartz Sand Mines, Belitung Timur
}

\section{Dede Rusmawan * dan Muzammil}

${ }^{1}$ BPTP Balitbangtan Kepulauan Bangka Belitung Jl. Mentok KM.4 Pangkalpinang 33134

*E-mail: dede.rusmawan212@ gmail.com

\begin{abstract}
The former quartz sand excavation land is a potential land for agricultural land. This land generally contains sufficiently high sand and very low fertility. The use of new superior varieties adaptive and tolerant can increase production. This study was carried out in the experimental field owned by BPTP in Gantong Village, East Belitung Regency, Bangka Belitung Islands Province. The design used was a randomized block design using three types of superior varieties, namely Inpari 22, Inpara 3, and Inpara 5. Each replication was repeated 3 times. Planting uses the jajar legowo system 4:1 (25 x 15) x $40 \mathrm{~cm}$ with 2-3 seedlings/planting holes. The fertilizer used is NPK 15:15:15 $300 \mathrm{~kg} / \mathrm{ha}$ and Urea $100 \mathrm{~kg} / \mathrm{ha}$. Urea fertilizer is given 3 (three) times each when plants are 7 days after planting (HST) as much as 25\%, 25 HST as much as 50\%, and 45 HST as much as 25\% dose. Lime and organic fertilizer with a dose of 1 ton/ha each. Parameters observed included plant height, number of tillers, and production. The results of the study indicate that the growth of Inpara 5 has better than other varieties. The highest plant height and number of tillers are owned by Inpara 5, but not significantly different than Inpara 3 and Inpari 22. From the aspect of production Inpara $5(2.23 \mathrm{t} / \mathrm{ha})$ is significantly different from the varieties Inpara 3 (1.51 t/ha) and not significantly different from Inpari 22 (2.21 t/ha).
\end{abstract}

Keywords: Quartz sand, VUB, paddy

Disubmit : 12 Januari 2019; Diterima: 20 Maret 2019, Disetujui : 29 April 2019

\section{PENDAHULUAN}

Sistem pertambangan di Indonesia menerapkan teknik penambangan permukaan (Surface mining), maka akibat yang ditimbulkan adalah berubahnya topografi, permukaan tanah menjadi rusak termasuk hilangnya flora dan fauna yang hidup di atasnya (Pratiwi et al., 2012). Areal bekas penambangan timah meninggalkan kolong-kolong berupa kolam dan hamparan tailing kuarsa dan overburden. Tanah bekas tambang timah, umumnya mengandung pasir dan kuarsa yang cukup tinggi, sehingga kesuburannya sangat rendah.

Kabupaten Belitung Timur merupakan salah satu kabupaten yang memiliki lahan bekas tambang pasirkuarsa cukup luas. Menurut masyarakat setempat Belitung Timur memiliki luas lahan bekas galian pasir kuarsa ribuan hektar yang telah ditambang selama kurun waktu tahun 1970-2009 yang lalu. Lahan bekas galian pasir kuarsa tersebut merupakan lahan yang potensial untuk dikembangkan menjadi areal pertanian yang produktif, namun masyarakat sekitar belum memanfaatkan lahan tersebut secara optimal sehingga lahan tersebut hanya terbengkalai begitu saja, sedangkan lahan bekas galian pasir kuarsa tersebut memiliki peran yang sangat strategis karena berada dipusat persawahan Kabupaten Belitung Timur yang memiliki luas 1.500 hektar (Rusmawan, 2016) BPTP Balitbangtan Kepulauan Bangka Belitung telah mendapatkan 
lahan hibah dari Pemerintah Daerah Kabupaten Belitung Timur seluas 15 hektar. Lahan tersebut merupakan lahan bekas galian pasir kuarsa. Lahan yang telah dihibahkan itu telah dimanfaatkan menjadi kebun percobaan (KP) yang ditanami dengan tanaman padi dan tanaman palawija lainya seperti jagung, kacang tanah, kacang hijau, dan tanaman sayuran lainnya.

Lahan bekas galian pasir kuarsa memiliki banyak masalah bila hendak dikembangkan menjadi lahan pertanian produktif seperti untuk penanaman komoditas padi sawah, masalah yang dihadapi seperti tingginya tingkat kemasaman tanah dan air serta kadar logam lainnya yang dapat meracuni tanaman. Disamping itu adalah masalah kesuburan tanah pada lahan bekas galian pasir kuarsa, dimana tanah lapisan atas yang berupa pasir mudah meloloskan air serta sangat sedikit bahan organik yang sangat dibutuhkan akar tanaman. Sementara itu lapisan bawah yang berupa liat dan pasir batu dapat dijadikan lapisan kedap guna menahan laju kehilangan air.

Untuk mengatasi masalah yang terjadi pada lahan bekas galian pasir kuarsa perlu diterapkan inovasi teknologi berupa pengelolaan hara dan air yang tepat, dapat berupa perbaikan kesuburan tanah dengan pemberian pupuk organik dan pupuk anorganik, pemberian pembenah tanah, dan pupuk hayati, serta pengelolaan air baik secara intermittent dan secara tergenang terus-menerus. Disamping itu yang sangat penting adalah penggunaan VUB padi sawah yang adaptif pada lahan bekas galian pasir kuarsa. Hasil pengkajian yang telah dilakukan oleh Dede Rusmawan et,al. (2016), pada lahan bekas galian pasir kuarsa di Kebun Percobaan (KP) Gantong, Belitung Timur menunjukan bahwa tanaman padi varietas Inpari 30, Inpari 34. Inpari 38, Inpari 39, dan Inpago 8 memiliki produktivitas masing-masing sebesar 2,21 t/ha, 3,12 t/ha, $2,27 \mathrm{t} / \mathrm{ha}$, dan 1,74 t/ha. Penggunaan varietas unggul yang adaptif dikombinasikan dengan penambahan bahan organik mampu mempercepat reklamasi lahan bekas galian pasir kuarsa. Adapun tujuan dari penelitian ini adalah untuk mengetahui keragaan dan produktivitas 3 VUB padi di lahan bekas tambang dan melihat pengaruhnya terhadap perbaikan lahan.

\section{METODE PENELITIAN}

Pelaksanaankegiatan di mulai dari bulan April sampai bulan Desember 2017. Lokasi Kebun Percobaan Gantung, di Desa Gantung, Kecamatan Gantung Kabupaten Belitung Timur Provinsi Kepulauan Bangka Belitung. Alat yang digunakan pada kajian ini adalah Traktor tangan, cangkul, ember, tali, meteran, alat tulis, dan alat dukung lainnya. Sedangkan bahan yang digunakan antara lain benih padi varietas Inpari 22, Inpara 3, Inpara 5, pupuk organik, pupuk anorganik, insektisida, fungisida, kapur dolomit, dan bahan pendukung lainnya.

Rancangan Pengkajian. Pengkajian ini menggunakan rancangan acak kelompok dengan tiga perlakuan jenis VUB padi, yaitu: Inpari 22 (V1), Inpara 3 (V2) dan Inpara 5 (V3). Setiap perlakuan diulang sebanyak 3 kali.

\begin{tabular}{ccc}
\hline $\mathrm{V}_{1}$ & $\mathrm{~V} 3$ & $\mathrm{~V} 2$ \\
\hline $\mathrm{V}_{3}$ & $\mathrm{~V} 2$ & $\mathrm{~V} 1$ \\
\hline $\mathrm{V}_{2}$ & $\mathrm{~V} 1$ & $\mathrm{~V} 3$ \\
\hline I & II & III
\end{tabular}

Pelaksanaan. Pengolahan tanah dilakukan 2 (dua) kali, yaitu pengolahan tanah pertama kali dilakukan dengan bajak singkal (kedalaman $10-20 \mathrm{~cm}$ ) dan pengolahan tanah kedua dilakukan dengan bajak sampai menjadi lumpur, kemudian dilakukan perataan tanah sampai siap tanam. Kapur dan pupuk organik/pupuk kandang diberikan pada saat pengolahan tanah yang pertama dengan dosis masing-masing 1 ton/ha. 
Penanaman menggunakan sistem tanam jajar legowo 4:1 (25 x 15) x $40 \mathrm{~cm}$ dengan 2-3 bibit/lubang tanam. Pupuk yang digunakan adalah NPK 15:15:15 $300 \mathrm{~kg} / \mathrm{ha}$ dan Urea $100 \mathrm{~kg} / \mathrm{ha}$. Pupuk urea diberikan 3 (tiga) kali masing-masing pada saat tanaman berumur 7 hari setelah tanam (HST) sebanyak $25 \%$, 25 HST sebanyak $50 \%$, dan 45 HST sebanyak $25 \%$ dosis. Pemberian NPK diberikan pada pemupukkan pertama . Pengendalian hama dan penyakit dilakukan bila terdapat serangan pada tanaman.

Parameter Pengamatan. Parameter yang diamati meliputi parameter pertumbuhan dan hasil, yaitu tinggi tanaman, jumlah anakan, dan produksi pada saat panen.

Analisis Data. Data yang diperoleh dianalisis dengan Analisis Varian dan dilanjutkan dengan uji Duncan's Multiple Range Test (DMRT) 5\%.

\section{HASIL DAN PEMBAHASAN}

Kondisi Lokasi Pengkajian. Lokasi pengkajian dilaksanakan di kebun percobaan (KP) Gantong, Belitung Timur. Lahan bekas galian tersebut terdiri atas dua lapisan utama yaitu lapisan atas berupa pasir dengan kedalaman antara 5-50 cm, dan lapisan bawah berupa lapisan liat yang sangat padat serta keras (Compacted clay), dimana masyarakat setempat menamakannya dengan sebutan tanah Basokak atau batu pasir.

Lahan pasca tambang timah didominasi oleh hamparan tailing, overburden dan kolong. Tailing merupakan hasil limbah dari proses pemisahan bijih timah yang ada di tanah, dan tailing ini berupa pasir kuarsa. Materialnya mulai dari pasir hingga slime. Biasanya $>95 \%$ berupa pasir kuarsa (Pratiwi et al.,2012).

Tabel 1. Sifat fisik dan kimia tailing timah

\begin{tabular}{lcccc}
\hline Sifat Tanah & Lapisan 1 & Harkat & Lapisan 2 & Harkat \\
\hline $\mathrm{pH} \mathrm{H}_{2} \mathrm{O}$ & 4,7 & Masam & 4,6 & Masam \\
C organic (\%) & 1,43 & Rendah & 0,73 & Sangat rendah \\
N Total $(\%)$ & 0,11 & Rendah & 0,05 & Sangat rendah \\
Al-dd (me/100 g) & 0,94 & Tinggi & 1,33 & Tinggi \\
KTK (me/100 g) & 3,92 & Sangat rendah & 5,84 & Rendah \\
Kejenuhan basa (\%) & 12 & Sangat rendah & 7 & Sangat Rendah \\
Tekstur : & & & & \\
Pasir $(\%)$ & 82 & & 67 & \\
Debu (\%) & 10 & Pasir berlempung & 20 & Pasir berlempung \\
Liat $(\%)$ & 8 & & 13 & \\
Popilasi m.o (populasi/100 g) & 894 & & 152 & \\
\hline
\end{tabular}

Sumber : Subardja et al. (2009), Herwan et al. (2004)

Salah satu penyebab turunnya kualitas ekosistem adalah limbah tailing dari penambangan timah yang memiliki nilai pH yang rendah (asam) karena konsentrasi Aldd dan Fedd tinggi, kahat unsur hara phospat (P) dan Nitrogen $(\mathrm{N})$ serta kandungan bahan organik yang sangat rendah. Berbeda dengan tanah asli, tailing timah umumnya mengandung tekstur pasir dengan fraksi pasir dapat mencapai lebih dari $90 \%$ dengan kandungan hara yang sangat rendah (Asmarhansyah, 2015).

Keragaan Pertumbuhan dan Produksi Tanaman. Dari hasil analisis data, menunjukan bahwa padi varietas Inpara 5 menunjukan laju pertumbuhan dan produksi yang lebih baik dibandingkan varietas lainnya. Dari aspek pertumbuhan Inpara 5 memiliki tinggi tanaman dan jumlah anakan yang tinggi dibandingkan varietas Inpari 22 dan Inpara 3, sedangkan dari aspek produksi Inpara 5 berbeda nyata dibandingkan Inpara 3 dan tidak berbeda nyata dibandingkan Inpari 22. Keragaan tanaman dapat dilihat pada Tabel 1 di bawah ini. 
Tabel 1. Rerata tinggi tanaman, jumlah anakan, dan produksi tanaman padi

\begin{tabular}{llll}
\hline Perlakuan Varietas & Tinggi Tanaman $(\mathrm{cm})$ & Jumlah Anakan (Batang) & Produksi (t/ha) \\
\hline Inpari 22 & $84,33 \mathrm{a}$ & $11,33 \mathrm{a}$ & $2,21 \mathrm{a}$ \\
Inpara 3 & $72,63 \mathrm{a}$ & $8,00 \mathrm{a}$ & $1,51 \mathrm{~b}$ \\
Inpara 5 & $87,33 \mathrm{a}$ & $11,33 \mathrm{a}$ & $2,23 \mathrm{a}$ \\
\hline $\mathrm{CV}$ & 8,12 & 14,21 & 10,27 \\
\hline
\end{tabular}

Daya adaptasi setiap varietas terhadap kondisi biofisik lingkungan akan brpengaruh terhadap varibilitas pertumbuhan dan produksi (Gosh dan Kashyap, 2003). Menurut Qamara dan Setiawan (1995), bahwa adanya perbedaan karakter fenotipe yang tampak dari masing-masing varietas disebabkan oleh adanya perbedaan gen yang mengatur karakter tersebut. Hal ini sejalan dengan pendapat Yatim (1991), bahwa setiap gen memiliki pekerjaan sendiri-sendiri untuk menumbuhkan dan mengatur berbagai jenis karakter dalam tubuh organisme. Keragaman tersebut dipengaruhi oleh variasi genetik yang masing-masing varietas memiliki karakter yang khas. Menurut Sirappa et al. (2009) dan Suyamto (2010), bahwa ketersediaan $\mathrm{N}$ mempengaruhi pembentukan anakan dan tinggi tanaman. Selain itu, perbedaan tinggi tanaman antar varietas tersebut sangat dipengaruhi oleh perbedaan factor genetis masing-masing varietas. Keragaman genetis antara populasi menghasilkan keragaman ekspresi genetik pula (Sunarti et al., 2006; Sujitno et al., 2011).

Menurut Taryat et al. (2000); Krismawati, et al. (2011), bahwa perbedaan masa pertumbuhan total pada fase vegetatif, lebih dipengaruhi oleh sifat genetik atau tergantung pada sensitifitas dari varietas yang dibudidayakan terhadap lingkungan. Jumlah anakan setiap varietas ditentukan oleh interaksi antara genotipe dan lingkungan. Sirappa et al. (2009) berpendapat bahwa, panjang malai dipengaruhi oleh faktor genetik dari varietas serta daya adaptasi varietas itu pada lingkungan tumbuh tanaman. Panjang malai ini dapat diterima petani dengan baik bila memilki malai yang panjang dan gabah matang serempak.

Lahan bekas tambang pasir kuarsa bila dijadikan lahan sawah akan menghadapi permasalahan yang sama atau malah semakin rumit seperti kebutuhan air yang cukup banyak untuk pelumpuran; produktivitas tanah masih rendah; perubahan proses fisikokimia yang sedang berlangsung akibat penggenangan dapat mengganggu pertumbuhan tanaman, seperti keracunan besi atau mangan (Nursyamsi dkk, 2000). Pada kondisi lahan seperti ini diperlukan varietas padi yang toleran kekeringan, umur genjah, dan potensi hasil cukup tinggi. Hal ini mengingat bahwa inovasi penggunaan benih unggul mampu meningkatkan produktivitas sekitar 16-36\% (Satoto dkk, 2009). Dari hasil penelitian ini Inpara 5 cenderung lebih adaptif dibandingkan varietas Inpari 22 maupun Inpara 2.

Pembukaan lahan sawah baru akan menghadapi permasalahan seperti kebutuhan air yang cukup banyak untuk pelumpuran; produktivitas tanah masih rendah; perubahan proses fisikokimia yang sedang berlangsung akibat penggenangan dapat mengganggu pertumbuhan tanaman, seperti keracunan besi atau mangan (Nursyamsi dkk, 2000). Pada kondisi lahan seperti ini diperlukan varietas padi yang toleran kekeringan, umur genjah, dan potensi hasil cukup tinggi. Hal ini mengingat bahwa inovasi penggunaan benih unggul mampu meningkatkan produktivitas sekitar 16-36\% (Satoto dkk, 2009).

Selain varietas penggunaan bahan pembenah tanah seperti pemberian kapur juga dapat membantu peningkatan pertumbuhan akar tanaman padi. Kapur yang diaplikasi dengan lahan penanaman padi bereaksi dengan air sehingga terbentuk ion $\mathrm{Ca} 2+$ dan $\mathrm{Mg} 2+$. Menurut Wijaya (2008), kalsium berperan dalam pertumbuhan akar. Menurut Hanafiah (2005), bahwa pemberian kapur dapat memperbaiki sifat kimia dan biologi tanah sehingga tanah mampu menyediakan hara bagi tanaman. Selain itu pemberian kapur dapat mengurangi kandungan $\mathrm{Al}$ dan $\mathrm{Fe}$ tanah, yang mana kandungan $\mathrm{Al}$ dan $\mathrm{Fe}$ yang terlalu tinggi dapat menyebabkan penyerapan unsur hara esensial lainnya menjadi terhambat. Kapur dolomit yang diaplikasikan ke tanah kemudian bereaksi dengan air akan menghasilkan ion $\mathrm{Ca} 2+$ dan $\mathrm{Mg} 2+$ yang kemudian diserap oleh 
tanaman. Unsur kalsium (Ca) berperan dalam komponen dinding sel, dalam pembentukan struktur dan permeabilitas membran sel dan unsur magnesium (Mg) merupakan satu-satunya mineral penyusun klorofil, tanpa klorofil fotosintesis tanaman tidak akan berlangsung dan sebagai aktivator enzim.

Menurut Hakim et al. (1986) pengaruh kapur terhadap kimia tanah adalah berupa naiknya kadar Ca dan $\mathrm{pH}$ tanah, sehingga reaksi tanah mengarah ke netral sehingga terjadi penurunan kandungan Al-dd dan kejenuhan Al. Dengan naiknya $\mathrm{pH}$ tanah dan tersedianya beberapa hara yang dibutuhkan biologi tanah menciptakan suasana tumbuh yang baik bagi akar. Lingkungan tumbuh yang baik itu memungkinkan akar menjadi lebih luas. Akibat semuanya itu serapan hara menjadi lebih baik dan efisien. Meningkatnya serapan hara, akibat perbaikan sifat dan ciri tanah dengan kapur ini akan menyebabkan pertumbuhan dan produksi tanaman meningkat. Pada kondisi defisiensi $\mathrm{Mg}$ daun tanaman kemungkinan besar akan mengandung klorofil dalam konsentrasi rendah, sehingga fotosintesis akan terganggu dan selanjutnya tanaman akan mensintesis asimilat dalam jumlah kecil.

\section{KESIMPULAN}

Pertumbuhan Inpara 5 lebih baik dengan hasil produksi yang lebih tinggi daripada varietas lainnya pada lahan bekas tambang pasir kuarsa di Belitung Timur.

\section{DAFTAR PUSTAKA}

Ghosh, P., dan A.K. Kashyap. 2003. Effect of rice cultivars on rate of Nmineralization, nitrification and nitrifier population size in an irrigated ecosystem. Applied Soil Ecology (23):27 - 41.

Hakim N, Nyakpa M.Y, Lubis A.M, Nugroho S.G, Saul M.R, Diha M.A, Hong G.B, Bailey H.H. 1986. Dasar-dasar Ilmu Tanah. Lampung: Universitas Lampung

Hanafiah K.A. 2011. Dasar-dasar Ilmu Tanah. Jakarta: PT Raja Grapindo PersadaHakim N, Nyakpa M.Y, Lubis A.M, Nugroho S.G, Saul M.R, Diha M.A, Hong G.B, Bailey H.H. 1986. Dasar-dasar Ilmu Tanah. Lampung: Universitas Lampung.

Herwan, Issukindasyah, Suwardih, dan Sutiman. 2006. Pengkajian Sistem Usaha Tani Berbasis Tanaman Pangan dan Sayuran pada Lahan Bekas Galian Timah di Bangka Belitung. BPTP Kepulauan Bangka Belitung. Pangkalpinang

Krismawati, A., dan Z. Arifin,. 2011. Stabilitas hasil beberapa varietas padi lahan sawah. J. Pengkajian dan Pengembangan Teknologi Pertanian 14(2): 84-92.

Nursyamsi, D., L.R. Widowati, D. Setyorini, dan J. Sri Adiningsih. 2000. Pengaruh pengolahan tanah, pengairan terputus, dan pemupukkan terhadap produktivitas lahan sawah bukaan baru pada Inceptisols dan Ultisols Muarabeliti dan Tatakarya. Jurnal Tanah dan Iklim 18:29-38

Pratiwi, E. Santoso, dan M.Turjaman. 2012. Penentuan dosis bahan pembenah (ameliorant) untuk perbaikan tanah dari tailing pasir kuarsa sebagai media tumbuh tanaman hutan. Jurnal Penelitian hutan dan Konservasi Alam Vol. 9 No. 2 : 163-174.

Satoto, A. Darajad, S. Wahyuningsih. 2008. Benih dan Varietas Unggul Padi Sawah. Balai Besar Penelitian Tanaman Padi. Sukamandi.

Sirappa, M.P., dan Edwen D. Waas, 2009. Kajian varietas dan pemupukan terhadap peningkatan hasil padi sawah di dataran Pasahari, Maluku Tengah. J. Pengkajian dan Pengembangan Teknologi Pertanian 12(1): 79-90

Suardi, D. 2002. Perakaran padi dalam hubungannya dengan toleransi tanaman terhadap kekeringan dan hasil. Jurnal Litbang Pertanian 21 (3). 
Subardja, D., A. Kasno, Hendri Sosiawan, Sutono, Wahyu Wahdini dan Uke Gunasyah. 2009. Survei Identifikasi Lahan Bekas Tambang Timah untuk Pencetakan Sawah di Perlang Kabupaten Bangka Tengah. Balai Besar Litbang Sumberdaya Lahan Pertanian. Tidak dipublikasikan.

Sujitno, E., T. Fahmi dan S. Teddy., 2011. Kajian adaptasi beberapa varietas unggul padi gogo pada lahan kering dataran rendah di Kabupaten Garut. J. Pengkajian dan Pengembangan Teknologi Pertanian 14(1): 62-69.

Sunarti, S., A. S. Nuning, M.D. Marsum. 2006. Keragaan Hasil 24 Jagung Bersari Bebas Pada Lahan Masam Pasang Surut di Kabupaten Kapuas Kalimatan Tengah. Widyariset (9(3): 203-208

Suyamto.2010. Masalah Lapang Hama Penyakit Hara Pada Padi. Balai Pengkajian Teknologi Pertanian Kep. Bangka Belitung.

Wijaya K.A. 2008. Nutrisi Tanaman. Jakarta: Prestasi Pustaka Publisher.

Qamara, W., dan A. Setiawan. 1995. Pengantar produksi benih. PT. Raja Grafindo Persada. Jakarta.

Yatim, W. 1991. Genetika. Penerbit Tarsito. Bandung 